\title{
Epidemiological Pattern of Lassa Fever Outbreak in Ondo State, Southwest Nigeria, 2014 to 2019
}

\author{
Elvis Efe Isere ${ }^{*}$, Temioluwa Fuwape ${ }^{2}$, Gboyega Adekunle Famokun ${ }^{3,4}$, Stephen Fagbemi ${ }^{4}$, \\ Akinola Ayoola Fatiregunn, Nosa Eniye Omorogbe ${ }^{6}$, Adewale Moses Adejugbagbe ${ }^{1}$, \\ Temitope Olajumoke Omoju ${ }^{3,4}$
}

${ }^{1}$ Department of Epidemiology and Medical Statistics, University of Ibadan, Ibadan, Nigeria

${ }^{2}$ George Mason University, Virginia, USA

${ }^{3}$ Nigeria Field Epidemiology and Laboratory Training Programme, Abuja, Nigeria

${ }^{4}$ Ondo State Ministry of Health, Akure, Nigeria

${ }^{5}$ World Health Organization, Ondo State Field Office, Akure, Nigeria

${ }^{6}$ Medical Laboratory Science Council of Nigeria, Abuja, Nigeria

Email: *elvisisere@gmail.com

How to cite this paper: Isere, E.E., Fuwape, T., Famokun, G.A., Fagbemi, S., Fatiregun, A.A., Omorogbe, N.E., Adejugbagbe, A.M. and Omoju, T.O. (2021) Epidemiological Pattern of Lassa Fever Outbreak in Ondo State, Southwest Nigeria, 2014 to 2019. Open Journal of Epidemiology, 11, 92-100.

https://doi.org/10.4236/ojepi.2021.111009

Received: January 25, 2020

Accepted: February 7, 2021

Published: February 10, 2021

Copyright $\odot 2021$ by author(s) and Scientific Research Publishing Inc. This work is licensed under the Creative Commons Attribution International License (CC BY 4.0).

http://creativecommons.org/licenses/by/4.0/

\begin{abstract}
Introduction: Annual outbreak of Lassa Fever (LF) has been reported in Ondo State over the years. We analyzed LF surveillance data from January 2014 to December 2019 to describe the epidemiological pattern of the outbreak. Method: Lassa fever dataset from January 2014 to December 2019 was obtained from the State Ministry of Health. Variables analyzed include date of onset of symptom, age, gender, place (Local Government Area, LGA) and outcome of laboratory test. Data were summarized using frequencies, proportions, chart and maps. Results: From January 2014 and December 2019, 2141 suspected LF cases were reported. Of these, 551 cases were laboratory confirmed with 134 deaths recorded. The LF cases (suspected vs. confirmed) reported increased in 2016 (73 vs. 19), 2017 (207 vs. 76), 2018 (452 vs. 159) and 2019 ( 856 vs. 285) respectively. Most of the confirmed cases (89.5\%) were $\geq 15$ years while more than half (53.7\%) were males. Prior to 2016, only two LGAs (Owo and Ose) recorded continued transmission of the disease. However, between 2016 and 2019, the disease had spread to 8 neighboring LGAs $(\mathrm{P}<$ 0.001) with the CFR declining from $67 \%$ in 2015 to $20 \%$ in 2019. Conclusion: We found an unusual increase in the suspected LF cases reported between January 2016 and December 2019 with a corresponding increase in the confirmed cases and high annual case fatality rates. Hence, we recommend intensified surveillance activities to enhance timely reporting of cases and laboratory confirmation to ensure early commencement of treatment to reduce the case fatality rate.
\end{abstract}




\section{Keywords}

Lassa Fever, Outbreak, Epidemiological Pattern, Ondo State

\section{Introduction}

Lassa Fever (LF) is a highly infectious acute viral haemorrhagic illness caused by a virus belonging to the family Arenaviridae [1] [2]. The disease is characterized by fever, muscle aches, sore throat, nausea, vomiting, chest and abdominal pain and haemorrhage from the body's orifices [3]. It is a zoonotic disease whose natural reservoir is a "Multimammate rat", Mastomys natalensis.

The primary mode of spread is from rodent to man through contact with the rodent's excreta or urine in food or during hunting and processing of rats for consumption or by consumption of food item contaminated with rat's excreta/urine containing the virus [4]. The virus has the capacity for person-to-person spread, either within households during care for sick relatives or in health care settings [4]. Percutaneous or per-mucosal exposure to blood and other infected body fluids, especially if the fluids contain blood, can result in secondary human spread. This type of transmission is the most likely route of transmission in health care settings [5]. Transmission of the disease has also been reported among rural farmers who practice open air drying of the farm produce [6].

The disease is endemic in Nigeria and other parts of West Africa and outbreaks have been reported annually [7]. Ondo State in south west, Nigeria has been classified by the Federal Ministry of Health as one of the high-risk and endemic states for Lassa fever transmission in Nigeria with annual outbreak reported resulting in high morbidity and mortality [8]. This report seeks to provide the descriptive epidemiology of Lassa fever outbreak in the state for the past 6 years to further guide public health intervention.

\section{Methodology}

\subsection{Study Location}

Ondo state is one of the six states in the south west, Nigeria. The State has 18 LGAs with three senatorial districts; Ondo North, Central and South senatorial districts and a 2015 projected total population of about 4,489,756 based on the 2006 population census [9]. The climate of the state highly favours the agrarian activities and crops such as cocoa, kola nut, oil palm and arable crops like maize and tubers such as yam and cassava which are grown annually [10]. The vast majority of the population consists of peasant farmers cultivating food and cash crops at a small-scale level. Hunting and livestock farming are also major occupations of the populace of Ondo State with many rearing goats, sheep and while some are also into fish farming. Other economic activities in the state include trading and civil service [11]. 


\subsection{Data Management and Analysis}

Lassa fever case investigation forms and database for all reported cases from January 2014 to December 2019 were obtained from the Ondo State Ministry of Health. Also, Lassa fever yearly line-lists from January 2014 to December 2019 were also obtained. Available case notes of reported cases were retrieved from the health facilities and reviewed to validate information from other data sources. Only Lassa fever cases whose samples were tested by the national reference laboratory were included in the analysis. Reported cases whose samples were not tested including reported deaths (probable cases) were excluded from the analysis. Data on age, gender, date of onset of symptoms, location as at the time of onset, laboratory outcome and outcome of treatment of each Lassa fever case were analyzed using SPSS version 16.0 and were summarized using frequencies and percentages. Health-Mapper software application was also used to generate graphical charts of locations of the outbreak.

\section{Results}

The review found that between January 2014 to December 2019, Ondo State reported a total of 1141 suspected Lassa fever cases, from which 551 cases were confirmed by laboratory investigation with 134 deaths recorded (Figure 1 and Table 1). Majority of the confirmed cases were within the age groups of 15 years

1200

1000
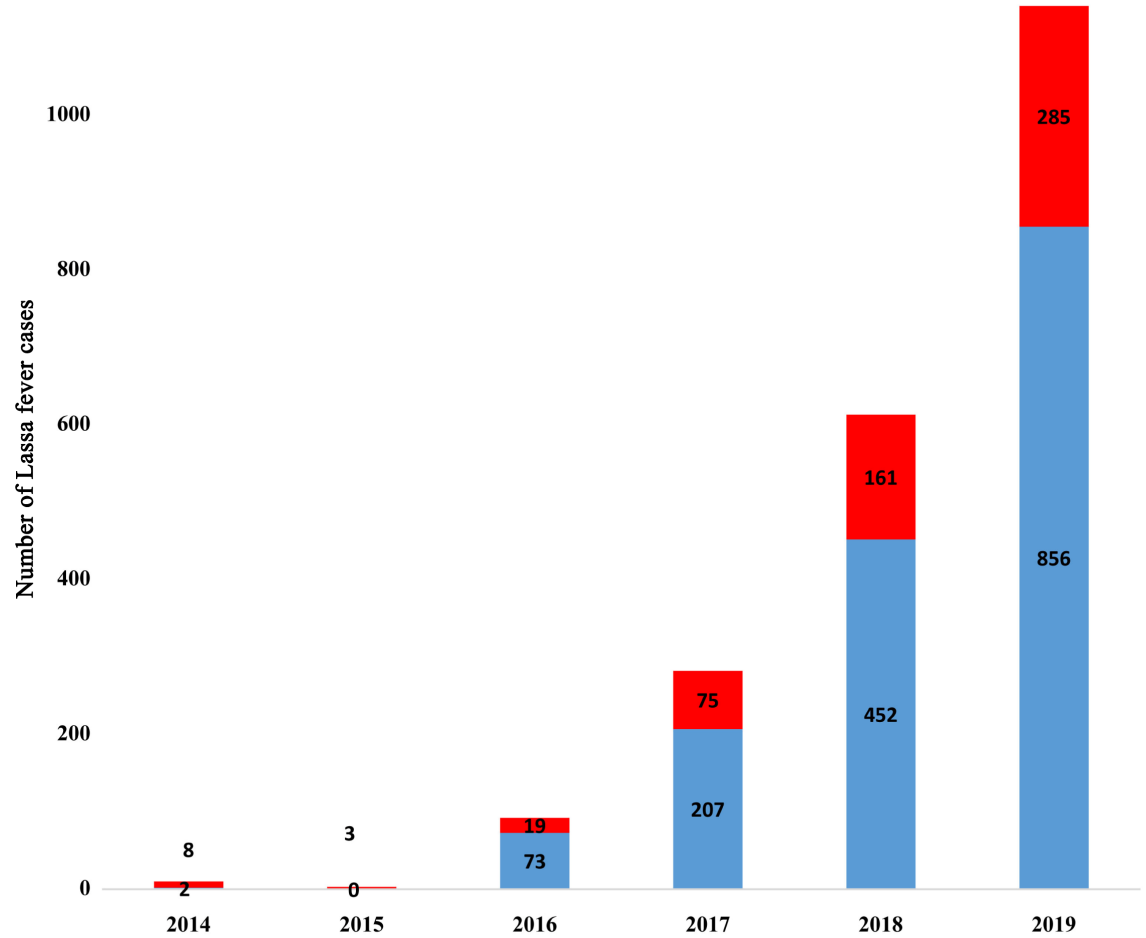

ॠ Suspected Cases reported $\quad$ Lassa fever cases confirmed by Lab

Figure 1. Trend of suspected and confirmed Lassa fever cases reported in Ondo State, January 2014 to December 2019. 
Table 1. Socio-demographic characteristics of Lassa fever confirmed cases in Ondo State January 2014 to December 2019.

\begin{tabular}{|c|c|c|c|c|c|c|c|}
\hline Variable & $\begin{array}{c}2014 \\
(\mathrm{~N}=8)\end{array}$ & $\begin{array}{c}2015 \\
(\mathrm{~N}=3)\end{array}$ & $\begin{array}{c}2016 \\
(\mathrm{~N}=19)\end{array}$ & $\begin{array}{c}2017 \\
(\mathrm{~N}=75)\end{array}$ & $\begin{array}{c}2018 \\
(N=161)\end{array}$ & $\begin{array}{c}2019 \\
(\mathrm{~N}=285)\end{array}$ & $\begin{array}{c}\text { Chi-Square/ } \\
\text { P Value }\end{array}$ \\
\hline \multicolumn{8}{|l|}{ Age group } \\
\hline$<5$ years & $0 \%$ & $0 \%$ & $16.0 \%$ & $1.3 \%$ & $1.9 \%$ & $7.0 \%$ & $25.3 / 0.005$ \\
\hline 5 - 14 years & $0 \%$ & $0 \%$ & $5.0 \%$ & $2.7 \%$ & $3.7 \%$ & $8.0 \%$ & \\
\hline$\geq 15$ years & $100 \%$ & $100 \%$ & $79.0 \%$ & $96.0 \%$ & $94.0 \%$ & $85.0 \%$ & \\
\hline \multicolumn{8}{|l|}{ Sex } \\
\hline Male & $25.0 \%$ & $67.0 \%$ & $47.0 \%$ & $51.0 \%$ & $56.0 \%$ & $54.0 \%$ & $3.9 / 0.558$ \\
\hline Female & $75.0 \%$ & $33.0 \%$ & $52.0 \%$ & $49.0 \%$ & $44.0 \%$ & $46.0 \%$ & \\
\hline \multicolumn{8}{|l|}{ LGA Affected } \\
\hline Idanre & $0 \%$ & $0 \%$ & $0 \%$ & $0 \%$ & $0.6 \%$ & $0 \%$ & $89.7 /<0.001$ \\
\hline Ileoluji-Okeigbo & $0 \%$ & $0 \%$ & $0 \%$ & $1.3 \%$ & $0 \%$ & $0 \%$ & \\
\hline Ondo West & $0 \%$ & $0 \%$ & $0 \%$ & $0 \%$ & $0.6 \%$ & $0.3 \%$ & \\
\hline $\begin{array}{c}\text { Akoko } \\
\text { South West }\end{array}$ & $0 \%$ & $0 \%$ & $0 \%$ & $2.7 \%$ & $3.7 \%$ & $7.0 \%$ & \\
\hline Akure North & $0 \%$ & $0 \%$ & $0 \%$ & $2.7 \%$ & $6.2 \%$ & $8.8 \%$ & \\
\hline Akure South & $0 \%$ & $0 \%$ & $32.0 \%$ & $5.3 \%$ & $84.9 \%$ & $7.0 \%$ & \\
\hline Ose & $100 \%$ & $67.0 \%$ & $5.0 \%$ & $17.3 \%$ & $14.0 \%$ & $14.3 \%$ & \\
\hline Owo & $0 \%$ & $33.0 \%$ & $63.0 \%$ & $71.0 \%$ & $69.5 \%$ & $62.0 \%$ & \\
\hline Ifedore & $0 \%$ & $0 \%$ & $0 \%$ & $0 \%$ & $0 \%$ & $0.3 \%$ & \\
\hline Okitipupa & $0 \%$ & $0 \%$ & $0 \%$ & $0 \%$ & $0 \%$ & $0.3 \%$ & \\
\hline
\end{tabular}

of age and above yearly $(\mathrm{P}<0.001)$ with slight gender difference recorded across the years in exception of 2014 where more females (75\%) were reported compared to males (25\%) and vice versa in 2015 (Table 1). There was an increase in the number of suspected cases reported, confirmed and case fatality recorded yearly from 2016 to 2019 (Figure 1, Figure 2 and Table 1). The epidemic curve by month of onset of symptom (Figure 3 ) shows a change in the season of transmission of the disease. Between 2014 to 2016, transmission of the disease was recorded between January and April of 2014 and 2016, however from January 2017 to December 2019, continued transmission of the diseases was reported all through the year. Figure 4 shows LGAs of transmissions from January 2014 to December 2019. Between 2014 and 2016, only 2 LGAs recorded transmission of Lassa fever in the state (Ose and Owo LGAs) however, from 2016 to 2019 the transmission of the disease has spread $(\mathrm{P}<0.001)$ to 8 additional LGAs (Okitipupa, Ondo West, Idanre, Akure South, Akure North, Ileoluji-Okeigbo, Akoko South West, Ifedore LGAs) (Figure 4). 


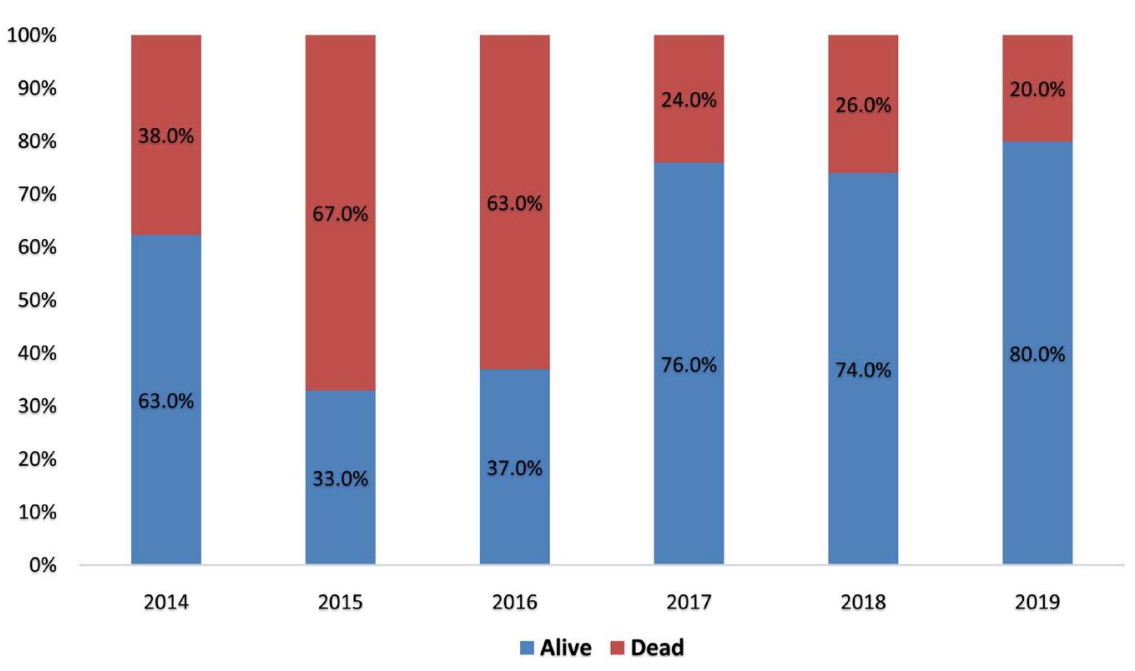

Figure 2. Trend of outcome of treatment of Lassa fever confirmed cases in Ondo State, January 2014 to December 2019.

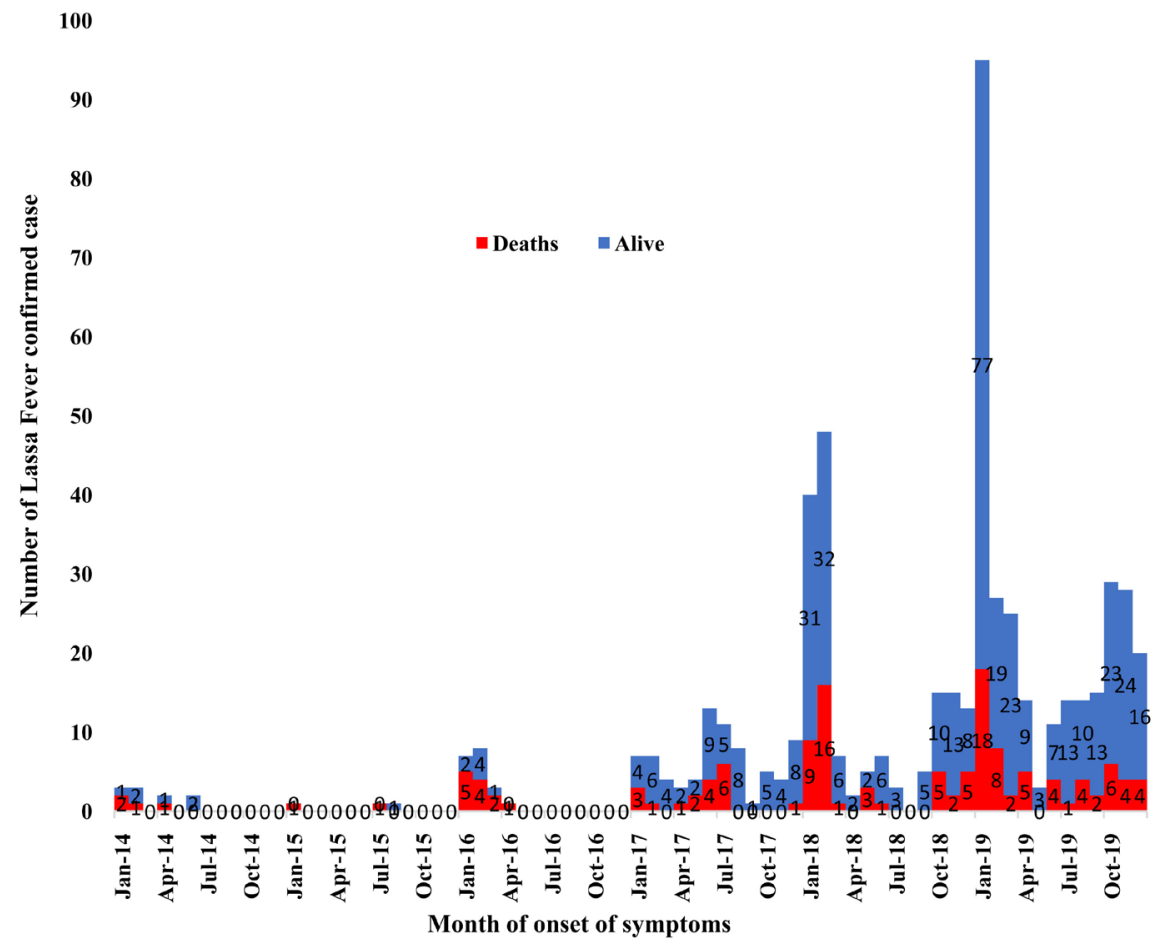

Figure 3. Epidemic curve of confirmed Lassa fever outbreak from January 2014 to December 2019 in Ondo state, south west Nigeria.

\section{Discussion}

The unusual increase in the number of suspected and confirmed cases of Lassa fever reported from 2016 to 2019 as found in this review could be attributed to heightened surveillance for Lassa fever cases by state surveillance officers and intensified risk communication and community awareness campaign within several LGAs in the state. Isere et al., [7] in their report on epidemiological investigation of Lassa fever in Ondo State in 2016 reported a coordinated Lassa 


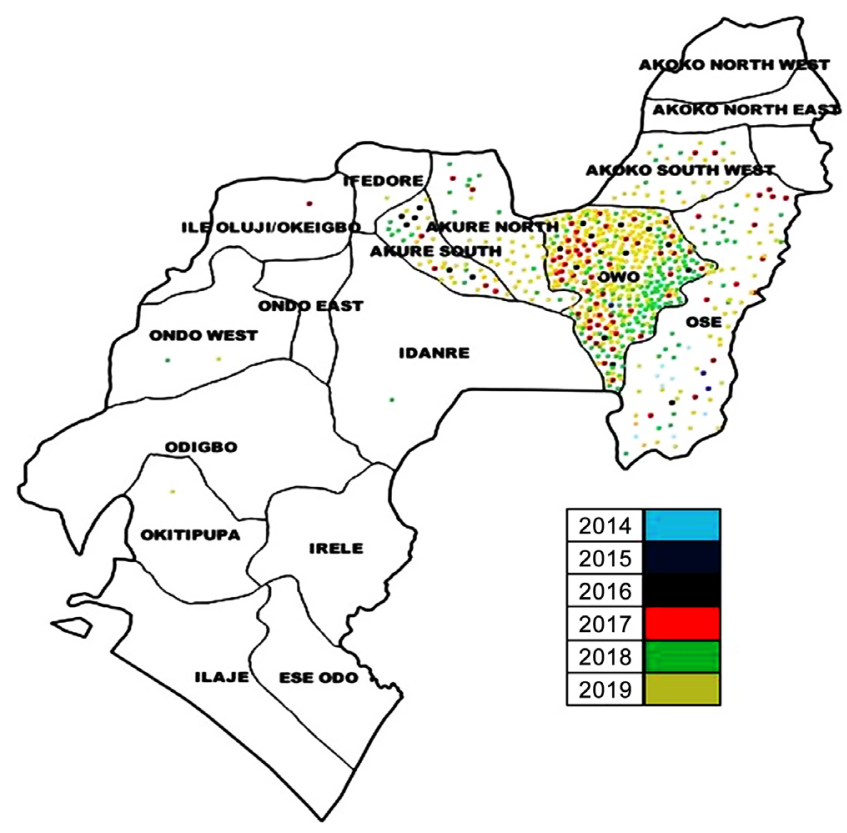

Figure 4. Distribution of confirmed Lassa fever cases in by LGA in Ondo state, January 2014 to December 2019.

fever outbreak investigation and response using the incident Management System (IMS) to strengthen surveillance for Lassa fever through active case search and sensitization of clinicians on having high index of suspicion, and the reporting of all suspected cases for laboratory confirmation. Also, Isere et al., [7] reported the implementation of several risk communication activities in the State through the mass media and reporting of all suspected cases by community members to the health facilities using community case definition of any person having fever and resistant malaria.

Furthermore, the high number of cases recorded during January to February yearly and all through 2017 to 2019 could be attributed to practices of bush burning among communities which causes the vectors responsible for the transmission of Lassa fever to migrate to households in search of food items for survival. Isere et al., [7] during their investigation of Lassa fever outbreak in Ondo State reported that majority of confirmed cases were through rodent-human transmission. In addition, Siddle et al., [12] reported from their genomic analysis of samples of confirmed cases during the 2018 outbreak in Nigeria that the transmission of Lassa fever in the country have been sustained through cross species transmission from local rodent population. This was further strengthened by their phylogenetic analysis which revealed extensive viral diversity that was structured according to geography, with major rivers between states appearing to act as barriers to migration of the rodent's reservoir [12].

The spread of the disease from the two endemic LGAs (Owo and Ose) to other neighbouring LGAs from 2016 to 2019 could be attributed to migration of these local rodents from these endemic LGAs to other LGAs (Figure 3). An enhanced community awareness campaign on Lassa fever across several LGAs in 
the state could have strengthened community surveillance for the disease with more suspected cases initially not reported or formerly attributed to spiritual beliefs now reported for laboratory testing and case management in these LGAs [7].

High CFR ( $\geq 20 \%$ ) were recorded yearly from 2014 to 2019 however, the CFR declined from 2016 to 2019 (Table 1). This could be attributed to improved case management of confirmed cases in the state which includes the establishment of a Lassa fever mobile diagnostic and treatment center at a tertiary health institution (Federal Medical Centre, Owo) in 2017 which could have enhanced early diagnosis and treatment of confirmed cases, development of a Lassa fever case management protocol and training of personnel for quality case management by the Nigeria Centre for Disease Control (NCDC) [13]. Also, early reporting of all suspected cases through intensified health facility and community surveillance network in all LGAs may have also played a key role [13].

We presume that the different level of exposures between male and female in this review from 2014 to March 2019 may have been responsible for the variation in gender among the confirmed cases recorded although, gender role has been shown to be a significant factor in the transmission of LF and other VHFs [14]. Most of the confirmed LF cases from 2014-March 2019 were in the age group $\geq 15$ years. Ajayi et al., [15] in a similar investigation of LF outbreak in Ebonyi State Southeast Nigeria, reported that almost all the cases recorded during the outbreak were in the older age group of $\geq 20$ years. However, missing data in the line-list and other data sources used for this review for key variables like occupation made it difficult to explain the higher cases recorded among older age group.

One main limitation of this review is missing variables on the line list and availability of all case investigation forms used for this analysis however, other key variables such as gender, LGA of onset of symptom, age, date of onset of symptoms, outcome of laboratory testing, outcome of treatment were available and analyzed.

\section{Conclusion}

We found an unusual increase in the number of suspected LF cases reported between January 2016 and December 2019, with a corresponding increase in the cases confirmed by laboratory and yearly high case fatality rate. Hence, we recommend improved surveillance activities community mobilization and awareness to ensure timely reporting of all suspected LF cases in the state, and immediate laboratory investigation and confirmation to ensure timely commencement of case management process to further reduce the case fatality rate.

\section{Conflicts of Interest}

The authors declare no conflicts of interest regarding the publication of this paper. 


\section{References}

[1] Bowen, M.D., Rollin, P.E., Ksiazek, T.G., Hustad, H.L., Bausch, D.G., Demby, A., Bajani, M.P., Peters, C.J. and Nichol, S.T. (2000) Genetic Diversity among Lassa Virus Strains. Journal of Virology, 74, 6992-7004. https://doi.org/10.1128/JVI.74.15.6992-7004.2000

[2] Ekuma, A.E and Akpan, I.S. (2017) Lassa Fever and Infection Control: Knowledge, Attitudes and Practice in a University Teaching Hospital in Uyo, Nigeria. Ibom Medical Journal, 10, 40-47.

[3] Richmond, J.K. and Baglole, D.J. (2003) Lassa Fever: Epidemiology, Clinical Features and Social Consequences. BMJ, 327, 1271-1275. https://doi.org/10.1136/bmj.327.7426.1271

[4] Fisher-Hoch, S.P. (2005) Lessons from Nosocomial Viral Haemorrhagic Fever Outbreaks. British Medical Bulletin, 73-74, 123-137. https://doi.org/10.1093/bmb/ldh054

[5] Aranoff, S.A., Lacy, M.A. and Smego Jr., R.A. (1997) Viral Hemorrhagic Fevers. In: Aranoff, S.A., Ed., Advances in Pediatric Infectious Diseases, Mosby Year Book, St. Louis, 21-53.

[6] Adefisan, A.K. (2014) The Level of Awareness That Rat Is a Vector of Lassa Fever among Rural People of Ijebu North Local Government Area of Ogun State, Nigeria. Journal of Education and Practice, 5, 166-170

[7] Isere, E.E., Fatiregun, A., Ilesanmi, O., Ijarotimi, I., Egube, B., Adejugbagbe, A., et al. (2018) Lessons Learnt from Epidemiological Investigation of Lassa Fever Outbreak in a Southwest State of Nigeria December 2015 to April 2016.

http://currents.plos.org/outbreaks/?p=77487

https://doi.org/10.1371/currents.outbreaks.bc4396a6650d0ed1985d731583bf5ded

[8] Fatiregun, A.A. and Isere, E.E. (2017) Epidemic Preparedness and Management: A Guide on Lassa Fever Outbreak Preparedness Plan. Nigerian Medical Journal, 58, 1-6. https://doi.org/10.4103/0300-1652.218414 http://www.ncbi.nlm.nih.gov/pubmed/29238121

[9] Igbalajobi, O., Fatuase, A.I. and Ajibefun, I. (2013) Determinants of Poverty Incidence among Rural Farmers in Ondo State, Nigeria. American Journal of Rural Development, 1, 131-137

[10] Adeyanju, D., Fatiregun, A.A., Famiyesin, W., Mkanda, P., Vaz, R.M., Isere, E., et al. (2016) Investigation of an Outbreak of Acute Methanol Poisoning in a South-West State of Nigeria. International Journal of TROPICAL DISEASE \& Health, 14, 1-8. https://doi.org/10.9734/IJTDH/2016/24464

[11] Amos, T.T. (2007) An Analysis of Productivity and Technical Efficiency of Smallholder Cocoa Farmers in Nigeria. Journal of Social Sciences, 15, 127-133. https://doi.org/10.1080/09718923.2007.11892573

[12] Siddle, K.J., Eromon, P., Barnes, K.G., Mehta, S., Oguzie, J.U., Odia, I., et al. (2018) Genomic Analysis of Lassa Virus during an Increase in Cases in Nigeria in 2018. New England Journal of Medicine, 379, 1745-1753. https://doi.org/10.1056/NEJMoa1804498

[13] Nigeria Centre of Disease Control (2018) National Guideline for Lassa fever case management, November 2018.

https://ncdc.gov.ng/themes/common/docs/protocols/92 1547068532.pdf

[14] WHO Ebola Response Team (2014) Ebola Virus Disease in West Africa-The First 9 Months of the Epidemic and Forward Projections. New England Journal of Medi- 
cine, 371, 1481-1495. https://doi.org/10.1056/NEJMoa1411100

[15] Ajayi, N.A., Nwigwe, C.G., Azuogu, B.N., Onyire, B.N., Nwonwu, E.U., Ogbonnaya, L.U., Onwe, F.I., Ekaete, T., Günther, S. and Ukwaja, K.N. (2013) Containing a Lassa Fever Epidemic in a Resource-Limited Setting: Outbreak Description and Lessons Learned from Abakaliki, Nigeria (January-March 2012). International Journal of Infectious Diseases, 17, e1011-e1016. https://doi.org/10.1016/j.ijid.2013.05.015 